\title{
Çocukların Devam Ettikleri Okul Türüne Göre Annelerin Çocuk Kitapları Hakkındaki Görüşlerinin İncelenmesi
}

\section{The Examination of the Mothers's Opinions on the Children's Books according to Types of Schools continued by Children}

\author{
Vedat BAYRAKTAR*, Özlem ERSOY**
}

\begin{abstract}
Öz: Araştırma, 4-6 yaş grubu çocukların devam ettikleri okul türüne göre annelerin çocuk kitabı hakkındaki görüşlerini tespit etmek amacıyla yapılmıştır. Araştırmada tarama araştırması yöntemi kullanılmıştır. Araştırmaya, Ankara il merkezinde yaşayan ve uygun örnekleme yöntemiyle seçilen toplam 500 anne katılmıştır. Veriler SPSS 20.00 paket programı kullanılarak Ki Kare $\left(\mathrm{X}^{2}\right)$ ile analiz edilmiştir. Annelere, "Okul Öncesi Dönemde Çocukları Bulunan Annelerin Çocuk Kitabı Seçim Kriterleri Anketi" uygulanmıştır. Ankette, annelere çocukların kendilerine kitap alınmasını nasıl karşıladıkları, çocuklarına kitap alma nedenleri, çocuklarına kitap alırken ne tür kitap tercih ettikleri, çocuklarına ödül ve hediye olarak ne aldıkları, çocukların arkadaşlarına ödül ve hediye olarak ne aldıkları, çocuklarını kütüphaneye götürme durumları, annelerin kendilerine kitap alma sıklıkları, çocuklarına kitap alma sıklıkları ve çocuklara kitap alınırken tercihi kimin yaptığına yönelik sorular sorulmuştur. Araştırma sonucunda; çocukların devam ettikleri okul türüne göre kendilerine kitap alınmasından hoşlanma durumları, kitap alma nedenleri, çocuklarına aldıkları ödül veya hediyelerin dağılımı, çocukların arkadaşlarına aldıkları ödül veya hediyelerin dağılımı, çocuklarını kütüphaneye götürme durumları, annelerin kendilerine kitap alma sıklıkları, annelerin çocuklarına kitap alma sıklıkları ve kendilerine kitap alınırken tercihi kimin yaptığı konularında istatistiksel olarak anlamlı bir fark bulunurken; çocuklarına ne tür kitaplar tercih ettikleri konusunda istatistiksel olarak anlamlı bir farklılık bulunmamıştır.

Anahtar Kelimeler: Okul öncesi dönem, çocuk kitabı, çocuk edebiyatı
\end{abstract}

\begin{abstract}
The study is conducted in order to determine the opinions of the mothers, who have in the 4-6 year-old group, on the children's book choice according to types of schools continued by children. Survey method has been used in the research. A total of 500 mothers living in Ankara city center and selected by appropriate sampling method have participated in the research. The data has been analyzed with Chi Square $\left(\mathrm{X}^{2}\right)$ in the SPSS 20.00 package program. "Questionnaire for selection of children's books for children in preschool period" has been applied to the mothers. The mothers in the questionnaire have been asked about the reasons for the children to receive books, how to buy books for their children, what kind of books they chose for their children, what they received as prize and gifts for their children, what they received as prize and gifts for their friends, the frequency of taking books with their children, and the questions about who made the choice while taking the book to the children.In the result of the research a statistically significant difference has been found in the subjects: the case of the children's like bought themselves book, book purchase reasons, the distribution of prize or gifts they receiving for their children, mothers taking their children to the library, the distribution of prize or gifts children buying their friends, the frequency of taking books for themselves, the frequency of mothers taking books for their children and who make the choice while they are buying the book; but there was no statistically significant difference in what kind of books they preferred to their children.
\end{abstract}

Keywords: Preschool, child books, child literature

Giriş

Okul öncesi dönem, çocuğun gelişiminin temellerinin atıldığ 1 ve kişiliğinin şekillendiği dönem olarak bilinmektedir. $\mathrm{Bu}$ dönemde edinilen temel bilgi, beceri ve alışkanlıklar çocuğun daha sonraki öğrenim yaşantısındaki başarının belirleyicisi olarak görülmektedir. Bu nedenle bu

\footnotetext{
*Arş.Gör.Dr., Gazi Universitesi, Ankara-Türkiye, ORCID: 0000-0003-1076-4736, e-posta: vbayraktar75@ gmail.com **Dr. Öğretim Üyesi, Gazi Universitesi, Ankara-Türkiye, ORCID: 0000-0002-7247-0517, e-posta: ozlemerso@gmail.com
} 
dönemde çocuğa verilen eğitim, sağlanan olanaklar ve edindiği deneyimler çocuk açısından önem kazanmaktadır. Okul öncesi dönemde çocuğa sunulacak olan zengin bir uyarıcı çevre çocuğun gelişimini desteklemek açısından önemli görülmektedir. Kitapların da bu ortamın parçalarından biri olduğu açıktır. Okul öncesi dönemde kazandırılması gereken alışkanlıklardan birisi de kitap okuma alışkanlığı ve kitap sevgisidir. Okul öncesi dönemde kitap okuma alışkanlığının ve kitap sevgisinin temelinin atılması, çocuk edebiyatı ürünlerinin aileler ve okul öncesi eğitim kurumlarındaki öğretmenler tarafından çocuğa sağlanmasıyla mümkün olacaktır.

Çocuğun okul öncesi dönemde kitapla ilgili deneyimleri, onun ilerki y1llarda kitaplara ve okumaya karşı olumlu duygu ve tutumları beslemesindeki sürecin ilk adımıdır. Okul öncesi dönemde çocuk tarafından edinilen tutumların model alma yoluyla kazanıldığı düşünüldüğünde bu dönemdeki yaşantıların çocuk açısından ne kadar önemli olduğu görülmektedir (Gürkan, 1993; Oktay, 2002).

Çocukların ilk öğretmenleri ebeveynleri olmaktadır. Dolayısıyla çocukların kitaba karşı olumlu duygular beslemesinde anne-babalar oldukça etkilidirler. Anne-babaları tarafindan çocuğa kitap okunması, onların okumaya ve kitaba karşı pozitif duygular içerisinde olmalarını sağlamaktadır. Çocukların kitaba ve okumaya karşı duygu ve düşünceleri anne ve babalarının çocukla girdikleri etkileşimlerle doğrudan ilişkilidir (Epspinosa ve Burns 2003; Griffith, Beach, Ruan ve Dunn, 2008; Machado, 2003; Wortham, 2005).

Okul öncesi dönemde kitap, çocuğun gelişiminin desteklenmesi açısından önemli bir uyarıcı olarak görülmektedir. Bu dönemde çocukların kitapla olan deneyimleri; kelime hazinesi, cümle yapısı, kendini ifade etme, anlama, dinleme, dilden zevk alma, düşünme vb. sözel dil becerilerinin gelişimini desteklemektedir. Çocuğun okul öncesi dönemdeki kitapla olan yaşantıları çocukta kitaba ve okumaya karşı olumlu tutum geliştirmesinin yanında onun gelecekteki okul başarısının da belirleyicisidir (Brock ve Rankin 2008; DeTemple, 2001; Epspinosa ve Burns, 2003; Ersoy ve Bayraktar, 2015; Griffith ve diğerleri 2008; Huck, Kiefer, Hepler ve Hickman, 2004; Wortham, 2005).

Çocuğun kitapla tanışmasının kendi bedeniyle ilgili zihin faaliyetleri dışında nesnelere odaklanmasıyla, yani ikinci döngüsel tepkiler döneminde, 4-8. aylarda başlaması gerekmektedir. Çünkü bu dönem bebeklerin nesneler ve resimlerle ilgilenmeye başladıkları dönemdir. $\mathrm{Bu}$ dönemde bebekler kitapları tutup ağızlarına götürebilir ve yırtabilir. $\mathrm{Bu}$ nedenle bebeklere, kolay yırtılan, buruşan ve kirlenen kitapların yerine yıkanabilir ve silinebilir özellikte olan vinleksten ya da bezden imal edilmiş kitaplar sunulması daha uygun olur. Yapılan araştırmalarda, bebeklerin 4. aydan sonra kitaplarla ilgilendikleri, baktıkları ve okunanlara karş1 tepkide bulundukları tespit edilmiştir (Beyazova 2006; Huck ve diğerleri 2004; Machado 2003; Özel, 2006; Soderman, Gregory ve McCarty, 2005).

Çocuğun yaşına, ilgi ve ihtiyacına cevap verebilecek nitelikte kitap sunulması ve kendisine okunmasından zevk aldığı edebi eserler olması onun kitap ile arasında olumlu bir bağ kurulabilmesini sağlamaktadır. Bu nedenle ebeveynlerin çocukların gelişim düzeylerine, ilgi ve ihtiyaçlarına uygun kitapların hangi eserler olduğunu bilmeleri ve buna göre çocuğa kitap seçmeleri gerekmektedir. Çocukların yaşına göre kitapların özellikleride farklılaşmaktadır. Örneğin, 2-3 yaş çocukları için hazırlanan kitaplarda genellikle metin yer alamazkan, 3 yaştan itibaren çocuğun kısa öykülerden zevk almaya başlamasıyla basit ve kısa öykülere yer verilebilir. Yani çocukların yaşına göre kitaplardaki hem iç hem de dış yapı özellikleri değişmektedir. Ebeveynler bu bilinçle, çocuğa gelişim, ilgi ve ihtiyacına uygun olan edebi eserleri seçebilirlerse, çocukta kitap sevgisinin gelişmesini olumlu yönde desteklemiş olurlar. $\mathrm{Bu}$ da çocukların da ileride iyi bir okuyucu olma olasılıklarını artıracaktır. Bu nedenle, okul öncesi dönemde çocukların ilgi, ihtiyaç ve gelişim özelliklerine uygun olan edebi eserlerle tanıştırılması gerekmektedir. Çocuğun gelişim düzeyine, ilgi ve ihtiyacına uygun edebi eserler seçimide onun kitaba ve okumaya karşı olumlu tutum ve alışkanlık geliştirmesine destek olmaktadır (Epspinosa ve Burns, 2003; Ersoy, Avc1 ve Turla, 2006; Hardman ve Jones, 1999; Oğuzkan, 2000; Tür, 2001).

Yukarıda yapılan açıklamalardan da anlaşılacağı gibi okul öncesi dönemde çocuğa hangi sıklıkla kitap alındığı, ne zaman alındığı, ne tür kitaplar tercih edildiği, ödül veya hediye 
olarak ne alındığı, çocuğun arkadaşlarına hediye olarak ne aldığı, çocukların kütüphaneye hangi sıklıkla götürüldüğü, çocuklara alınan kitaplarda hangi konulara yer verildiği, annelerin kendilerine hangi sıklıkla kitap aldığı, çocukların kendilerine kitap alınmasını nasıl karşıladıkları ve çocuklara kitap alınırken tercihi kimin yaptığı önem kazanmaktadır. Çocukları kitapla tanıştıran ve kitabı çocuğa sunan ilk kişiler anne-babalar ve özellikle de anneler olduğu bilinmektedir. Annelerin çocuklara hangi durumlarda kitap aldıkları, ne sıklıklarda aldıkları, ne tür kitapları tercih ettikleri ve seçimi kimlerin yaptığı önem kazanmaktadır. Bu çalışma, ülkemizdeki annelerin çocuklarının devam ettikleri okul türüne göre bu konularda ne durumda olduklarını saptamak amacıyla yapılmıştır. Böylelikle bu alanda yaşanan sorunlar saptanmış olacak ve çözüm stratejileri geliştirilebilecektir.

\section{Yöntem}

\section{Araştırma modeli}

$\mathrm{Bu}$ araştırmada; annelerin 4-6 yaş grubu çocuklarının devam ettikleri okul türüne göre çocuk kitabı hakkındaki görüşlerini incelemek amaçlanmıştır. Araştırmada, mevcut durumu olduğu gibi betimlemeyi amaçlayan bir yaklaşım olan betimsel model kullanılmıştır (Büyüköztürk, 2012).

\section{Çalışma grubu}

Okul öncesi dönemde (4-6 yaş) çocuğu olan, uygun örnekleme yöntemiyle seçilen toplam 500 anne katılmıştır. Araştırmaya 500 anne katılmış olmasına rağmen tablolardaki sütun sayıları 500 'den farklı olabilmektedir. Bu durum sorulara birden fazla cevap verenlerin olmasından ya da cevap verilmemesinden kaynaklanmaktadır.

\section{Veri toplama araçları}

Araştırmada, annelere araştırmacılar tarafından geliştirilen kişisel bilgi formu ve anket uygulanmıştır.

Kişisel bilgi formu: Kişisel bilgi formunda; çocuk cinsiyet ve yaşı; anne yaş ve öğrenim durumu gibi sorular sorulmuştur.

Okul Öncesi Dönemde Çocukları Bulunan Annelerin Çocuk Kitabı Seçim Kriterleri Anketi: Ankette, annelerin çocuklarının gittiği okul türüne göre çocuğa hangi sıklıkla kitap alındığı, ne zaman alındığı, ne tür kitaplar tercih edildiği, ödül veya hediye olarak ne alındığı, çocuğun arkadaşlarına hediye olarak ne aldığı, çocukların kütüphaneye hangi sıklıkla götürüldüğü, çocuklara alınan kitaplarda hangi konulara yer verildiği, annelerin kendilerine hangi sıklıkla kitap aldığı, çocukların kendilerine kitap alınmasını nasıl karşıladıkları ve çocuklara kitap alınırken tercihi kimin yaptığına yönelik sorulara yer verilmiş̧ir. Anket alanda çalışan yedi uzmanın görüşüne sunulmuş ve istenilen değişiklikler yapıldıktan sonra pilot uygulama yapılmıştır. Gerekli düzenlemelerden sonra ankete son şekli verilerek uygulamaya geçilmiştir. Yurdagül (2005) tarafindan yapılan araştırmada, kapsam geçerliliği açısından görüş alınan uzman sayısı yedi olduğunda $\alpha=0,05$ anlamlılık düzeyinde kapsam geçerlilik oranları (KGO) için minimum değer $=0.99$ olarak belirtilmiştir. Ankettede yedi kişiden uzman görüşü alındığ için $\alpha=0,05$ anlamlılık düzeyinde minimum değer $=0.99$ üstünde olan maddeler ankete dahil edilirken altında olan maddeler anketten çıkarılmıştır. Bu nedenle $\alpha=0,05$ anlamlılık düzeyinde $\mathrm{KGO}=0,99$ olarak alınmıştır.

\section{Verilerin analizi}

Veriler, SPSS 20.0 Paket Programı kullanılarak analiz edilmiştir. Analizler yapılmadan önce dağılımların normalliğine ve varyansların homojenliğine bakılmıştır. Annelerin çocuklarının gittiği okul türüne göre değişkenler, ki kare $\left(\chi^{2}\right)$ testi ile değerlendirilmiştir. Ki-kare $\left(\chi^{2}\right)$ testi, 
frekans dağılımları üzerinden işlem yapan bir analiz yöntemidir. Bu teknik iki kategorik ya da biri kategorik diğeri sıralamalı iki değişken arasında anlamlı bir ilişki olup olmadığını test etmektedir. İki değişken arasında ilişkinin olması, yani $\mathrm{p}<.05$, bir değişkenin düzeyinde verilen cevapların diğer değişkenin düzeylerinde farklılaşıp farklılaşmadığını göstermektedir (Büyüköztürk, 2012).

\section{Bulgular}

Bu bölümde, analizlerden elde edilen veriler aşağıda sunulmuştur.

Tablo 1.

Çocukların Devam Ettikleri Okul Türüne Göre Kendilerine Kitap Alınmasından Hoşlanma Durumlarının Dağılımı

\begin{tabular}{lllllllll}
\hline & \multicolumn{2}{l}{$\begin{array}{l}\text { Okula } \\
\text { Gitmiyor }\end{array}$} & \multicolumn{2}{l}{ Devlet Okulu } & \multicolumn{2}{l}{ Özel Okul } & \multicolumn{2}{l}{ Toplam } \\
\cline { 2 - 9 } & $\mathrm{N}$ & $\%$ & $\mathrm{~N}$ & $\%$ & $\mathrm{~N}$ & $\%$ & $\mathrm{~N}$ & $\%$ \\
\hline Hoşlaniyor & 101 & 92,7 & 202 & 99,0 & 176 & 97,2 & 479 & 97,0 \\
Hoşlanmıyor & 8 & 7,3 & 2 & 1,0 & 5 & 2,8 & 15 & 3,0 \\
\hline Toplam & 109 & 100,0 & 204 & 100,0 & 181 & 100,0 & 494 & 100,0 \\
\hline \multicolumn{1}{c}{$\left(\chi^{2}=9,83 ; \mathrm{p}<.001\right)}$. & & & & & & &
\end{tabular}

Tablo 1'de özel okula devam eden çocukların \%97, 2 ( $\mathrm{n}=176$ )'sinin; devlet okuluna giden çocukların \%99, $0(n=202)$ 'ının ve okula gitmeyen çocukların ise \%92, $7(n=101)$ 'sinin kendilerine kitap alınmasından hoşlandıkları görülmektedir. Çocukların devam ettikleri okul türüne göre kendilerine kitap alınmasından hoşlanma durumları istatistiksel olarak anlamlı bir fark göstermektedir.

Tablo 2.

Çocukların Devam Ettikleri Okul Türüne Göre Annelerin Çocuklarına Kitap Alma Nedenlerinin Dağılımı

\begin{tabular}{|c|c|c|c|c|c|c|c|c|}
\hline & \multicolumn{2}{|c|}{ Okula Gitmiyor } & \multicolumn{2}{|c|}{ Devlet Okulu } & \multicolumn{2}{|c|}{$\begin{array}{l}\text { Özel } \\
\text { Okul }\end{array}$} & \multicolumn{2}{|c|}{ Toplam } \\
\hline & $\mathrm{N}$ & $\%$ & $\mathrm{~N}$ & $\%$ & $\mathrm{~N}$ & $\%$ & $\mathrm{~N}$ & $\%$ \\
\hline Çocuğum istediği için & 40 & 36,4 & 98 & 48,0 & 64 & 35,2 & 202 & 40,7 \\
\hline Ödül olsun diye & 13 & 11,8 & 32 & 15,7 & 51 & 28,0 & 96 & 19,4 \\
\hline $\begin{array}{l}\text { Özel günlerde hediye } \\
\text { olarak }\end{array}$ & 8 & 7,3 & 14 & 6,9 & 17 & 9,3 & 39 & 7,9 \\
\hline Param olduğu için & 32 & 29,1 & 21 & 10,3 & 16 & 8,8 & 69 & 13,9 \\
\hline Öğretmen istediği için & 0 & 0,0 & 20 & 9,8 & 14 & 7,7 & 37 & 7,5 \\
\hline Diğer & 14 & 12,7 & 19 & 9,3 & 20 & 11,0 & 53 & 10,7 \\
\hline Toplam & 110 & 100,0 & 204 & 100,0 & 182 & 100,0 & 496 & 100,0 \\
\hline
\end{tabular}

$\left(\chi^{2}=42,29 ; \mathrm{p}<.001\right)$.

Tablo 2'de devlet okuluna giden çocukların annelerinin \%48,0'i ( $\mathrm{n}=98$ ), okula gitmeyen çocukların annelerinin \%36,4'ü $(\mathrm{n}=40)$ ve özel okula devam eden çocukların annelerinin $\% 35,2$ 'si (n=64) çocuklarına istediği için kitap aldıklarını belirtmiştir. Diğer bir neden olarak okula gitmeyen çocukların annelerinin ise $\% 29,1^{\prime} i(n=32)$; devlet okuluna giden çocukların annelerinin \% 10,3'ü $(\mathrm{n}=21)$ ve özel okula devam eden çocukların annelerinin \% 8,8'i $(\mathrm{n}=16)$ parası olduğu için kitap aldıklarını söylemiştir. Başka bir neden olarak özel okula devam eden çocukların annelerinin \% 28,0'i ( $\mathrm{n}=51)$; devlet okuluna giden çocukların annelerinin \% 15,7'si $(n=32)$ ve okula gitmeyen çocukların annelerinin ise \% 11,8'i $(n=13)$ ödül olsun diye kitap aldıklarını belirtmiştir. Ayrıca özel okula devam eden çocukların annelerinin \% 9,3'ü ( $\mathrm{n}=17)$; okula gitmeyen çocukların annelerinin \% 7,3'ü $(n=8)$ ve devlet okuluna giden çocukların 
annelerinin \% 6,9'u (n=14) özel günlerde hediye olarak aldığını; devlet okuluna giden çocukların annelerinin \% 9,8'i (n=20); özel okula devam eden çocukların annelerinin \% 7,7'si $(\mathrm{n}=14)$ öğretmen istediği için kitap aldıkları görülmektedir. Çocukların devam ettikleri okul türüne göre annelerin kitap alma nedenleri arasında istatistiksel olarak anlamlı fark göstermektedir.

Tablo 3.

Çocukların Devam Ettikleri Okul Türüne Göre Annelerin Çocuklarına Kitap Alırken En Çok Tercih Ettikleri Kitap Türlerinin Dağılımı

\begin{tabular}{|c|c|c|c|c|c|c|c|c|}
\hline & \multicolumn{2}{|c|}{$\begin{array}{l}\text { Okula } \\
\text { Gitmiyor }\end{array}$} & \multicolumn{2}{|c|}{$\begin{array}{l}\text { Devlet } \\
\text { Okulu }\end{array}$} & \multicolumn{2}{|c|}{$\begin{array}{l}\text { Özel } \\
\text { Okul }\end{array}$} & \multicolumn{2}{|c|}{ Toplam } \\
\hline & $\mathrm{N}$ & $\%$ & $\mathrm{~N}$ & $\%$ & $\mathrm{~N}$ & $\%$ & $\mathrm{~N}$ & $\%$ \\
\hline Boyama kitab1 & 38 & 33,6 & 32 & 15,7 & 15 & 8,1 & 85 & 16,9 \\
\hline Masalımsı hikâye & 20 & 17,7 & 35 & 17,2 & 32 & 17,3 & 87 & 17,3 \\
\hline Klasik çocuk masalları & 22 & 19,5 & 29 & 14,2 & 37 & 20,0 & 88 & 17,3 \\
\hline $\begin{array}{l}\text { Kavram geliştirici/okula } \\
\text { hazırlık kitapları }\end{array}$ & 26 & 23,0 & 84 & 41,2 & 83 & 44,9 & 193 & 38,4 \\
\hline $\begin{array}{l}\text { Tenten, Vikingler gibi } \\
\text { çizgi kitaplanı }\end{array}$ & 2 & 1,8 & 0 & 0 & 1 & 0,5 & 3 & 0,6 \\
\hline $\begin{array}{l}\text { Destan ve kahramanlık } \\
\text { kitapları }\end{array}$ & 0 & 0 & 0 & 0 & 2 & 1,1 & 2 & 0,4 \\
\hline Bilim kurgu hikâyeleri & 2 & 1,8 & 3 & 1,5 & 3 & 1,6 & 8 & 1,6 \\
\hline $\begin{array}{l}\text { Yazarları Türk olan } \\
\text { çocuk hikâyeleri }\end{array}$ & 3 & 3,7 & 21 & 10,3 & 12 & 6,5 & 36 & 7,2 \\
\hline Toplam & 113 & 100,0 & 204 & 100,0 & 185 & 100,0 & 502 & 100,0 \\
\hline
\end{tabular}

Tablo 3'de çocukların devam ettikleri okul türüne göre özel okula devam eden çocukların annelerinin \%44,9'u $(n=83)$; devlet okuluna devam eden çocukların annelerinin \%41,2'si (n=84) okula devam etmeyen çocukların annelerinin \%23,0'1 $(\mathrm{n}=26)$ çocuklarına kavram geliştirici/okula hazırlayıcı kitaplar aldıkları; okula devam etmeyen çocukların annelerinin ise \%33,6'sının ( $\mathrm{n}=34)$, devlet okuluna devam eden çocukların annelerinin \% 15,7'sinin ( $\mathrm{n}=32)$ özel okula devam eden annelerin ise \% 8,1'inin ( $\mathrm{n}=15)$ boyama kitabı aldığı; özel okula devam eden çocukların annelerinin \% 20,0'1 ( $\mathrm{n}=37)$; okula devam etmeyen çocukların annelerinin \%19,5'inin $(\mathrm{n}=22)$, devlet okuluna devam eden çocukların annelerinin ise \% 14,2'sinin ( $\mathrm{n}=29)$ çocuklarına klasik çocuk masal aldığı; okula devam etmeyen çocukların annelerinin \%17,7'sinin $(\mathrm{n}=20)$, özel okula giden çocukların \%17,3'ünün $(\mathrm{n}=32)$ ve devlet okuluna devam eden çocukların annelerinin \% 17,2'sinin $(n=35)$ ise, çocuklarına masalımsı hikâyeler aldıkları görülmektedir.

Tablo 4.

Çocukların Devam Ettikleri Okul Türüne Göre Annelerinin Çocuklarına Aldıkları Ödül veya Hediyelerin Dağılımı

\begin{tabular}{|c|c|c|c|c|c|c|c|c|}
\hline & \multicolumn{2}{|c|}{$\begin{array}{c}\text { Okula } \\
\text { Gitmiyor }\end{array}$} & \multicolumn{2}{|c|}{ Devlet Okulu } & \multicolumn{2}{|c|}{$\begin{array}{l}\text { Özel } \\
\text { Okul }\end{array}$} & \multicolumn{2}{|c|}{ Toplam } \\
\hline & $\mathrm{N}$ & $\%$ & $\mathrm{~N}$ & $\%$ & $\mathrm{~N}$ & $\%$ & $\mathrm{~N}$ & $\%$ \\
\hline Giysi & 14 & 12,4 & 17 & 8,3 & 23 & 12,6 & 54 & 10,8 \\
\hline Oyuncak & 53 & 46,9 & 101 & 49,3 & 84 & 45,9 & 238 & 47,5 \\
\hline Kitap & 8 & 7,1 & 25 & 12,2 & 34 & 18,6 & 67 & 13,4 \\
\hline Yiyecek & 16 & 14,2 & 22 & 10,7 & 14 & 7,7 & 52 & 10,4 \\
\hline Şeker veya çikolata & 15 & 13,3 & 9 & 4,4 & 12 & 6,6 & 36 & 7,2 \\
\hline Diğer & 7 & 6,2 & 31 & 15,1 & 16 & 8,7 & 54 & 10,8 \\
\hline Toplam & 113 & 100,0 & 205 & 100,0 & 183 & 100,0 & 501 & 100,0 \\
\hline
\end{tabular}


Tablo 4'te özel okula devam eden çocukların annelerinin \%45,9'u (n=84); devlet okuluna giden çocukların annelerinin \%49,3'ü $(n=101)$ ve okula gitmeyen çocukların ise $\% 46,9$ 'unun $(\mathrm{n}=53$ ) hediye veya ödül olarak çocuklarına oyuncak aldıkları; özel okula devam eden çocukların annelerinin \% 18,6'sının $(\mathrm{n}=34)$, devlet okuluna giden çocukların annelerinin \% 12,2 ' $\operatorname{sinin}(\mathrm{n}=25)$ ve okula gitmeyen çocukların annelerinin $\% 7,1^{\prime}$ inin $(\mathrm{n}=8)$ ise kitap aldıkları görülmektedir. Çocukların devam ettikleri okul türüne göre annelerin çocuklarına aldıkları ödül veya hediyeler istatistiksel olarak anlamlı bir fark göstermektedir.

Tablo 5.

Çocukların Devam Ettikleri Okul Türüne Göre Annelerin Çocuklarının Arkadaşlarına Almayı Tercih Ettikleri Hediyelerin Dağılımı

\begin{tabular}{|c|c|c|c|c|c|c|c|c|}
\hline & \multicolumn{2}{|c|}{$\begin{array}{c}\text { Okula } \\
\text { Gitmiyor }\end{array}$} & \multicolumn{2}{|c|}{ Devlet Okulu } & \multicolumn{2}{|c|}{$\begin{array}{l}\text { Özel } \\
\text { Okul }\end{array}$} & \multicolumn{2}{|c|}{ Toplam } \\
\hline & $\mathrm{N}$ & $\%$ & $\mathrm{~N}$ & $\%$ & $\mathrm{~N}$ & $\%$ & $\mathrm{~N}$ & $\%$ \\
\hline Giysi & 41 & 36,6 & 42 & 20,4 & 34 & 18,3 & 117 & 23,2 \\
\hline Oyuncak & 39 & 34,8 & 65 & 31,6 & 64 & 34,4 & 168 & 33,3 \\
\hline Kitap & 17 & 15,2 & 63 & 30,6 & 67 & 36,0 & 147 & 29,2 \\
\hline Şeker Çikolata & 10 & 8,9 & 9 & 4,4 & 7 & 3,8 & 26 & 5,2 \\
\hline Diğer & 5 & 4,5 & 27 & 13,1 & 14 & 7,5 & 46 & 9,1 \\
\hline Toplam & 112 & 100,0 & 206 & 100,0 & 186 & 100,0 & 504 & 100,0 \\
\hline
\end{tabular}

$\left(\chi^{2}=33,10 ; \mathrm{p}<.001\right)$.

Tablo 5'te özel okula devam eden çocukların annelerinin \%36,0'ının ( $\mathrm{n}=147)$; devlet okuluna giden çocukların annelerinin \%30,6'sının $(n=63)$ ve okula gitmeyen çocukların annelerinin ise \%15,2'sinin ( $\mathrm{n}=17)$ arkadaşlarının çocuklarına hediye olarak kitap aldıkları; özel okula devam eden çocukların annelerinin \%34,4'ünün $(n=64)$, devlet okuluna giden çocukların annelerinin \%31,6'sının $(n=65)$ ve okula gitmeyen çocukların annelerinin \%34,8'inin $(n=39)$ arkadaşlarına oyuncak aldıkları; okula gitmeyen çocukların annelerinin \%36,6'sının $(n=41)$ ise arkadaşlarına hediye olarak giysi aldıkları görülmektedir. Çocukların devam ettikleri okul türüne göre annelerin çocuklarının arkadaşlarına aldıkları ödül veya hediyeler arasında istatistiksel olarak anlamlı fark göstermektedir.

Tablo 6.

Çocukların Devam Ettikleri Okul Türüne Göre Annelerin Çocuklarını Kütüphaneye Götürme Durumlarının Dağılımı

\begin{tabular}{llllllrrr}
\hline & \multicolumn{2}{c}{ Okula Gitmiyor } & \multicolumn{2}{c}{ Devlet Okulu } & \multicolumn{2}{c}{ Özel Okul } & \multicolumn{2}{c}{ Toplam } \\
\cline { 2 - 9 } & $\mathrm{N}$ & $\%$ & $\mathrm{~N}$ & $\%$ & $\mathrm{~N}$ & $\%$ & $\mathrm{~N}$ & $\%$ \\
\hline Evet & 40 & 35,7 & 154 & 75,5 & 148 & 80,4 & 342 & 68,4 \\
Hayır & 72 & 64,3 & 50 & 24,5 & 36 & 19,6 & 158 & 31,6 \\
\hline Toplam & 112 & 100,0 & 204 & 100,0 & 184 & 100,0 & 500 & 100,0 \\
\hline \multicolumn{2}{c}{$\left(\chi^{2}=72,43 ; \mathrm{p}<.001\right)}$. & & & & & & &
\end{tabular}

Tablo 6'da özel okula devam eden çocukların \%80,4'ünü ( $n=148)$; devlet okuluna giden çocukların \%75,5'ini $(n=154)$ ve okula gitmeyen çocukların ise \%35,7'sini $(n=40)$ annelerinin kütüphaneye götürdüğü; okula gitmeyen çocukların 64,3'ünün $(n=72)$, devlet okuluna giden çocukların 24,5'inin $(n=50)$ ve özel okula giden çocukların 19,6'sını $(n=36)$ ise annelerin çocuklarını kütüphaneye götürmediği tespit edilmiştir. Çocukların devam ettikleri okul türüne göre annelerinin çocuklarını kütüphaneye götürme durumları istatistiksel olarak anlamlı fark göstermektedir. 
Tablo 7.

Çocukların Devam Ettikleri Okul Türüne Göre Annelerin Kendilerine Kitap Alma Sıklıklarının Dağılımı

\begin{tabular}{lllrrrrrr}
\hline & \multicolumn{2}{c}{ Okula Gitmiyor } & \multicolumn{2}{c}{$\begin{array}{l}\text { Devlet } \\
\text { Okulu }\end{array}$} & \multicolumn{2}{c}{$\begin{array}{c}\text { Özel } \\
\text { Okul }\end{array}$} & \multicolumn{2}{c}{ Toplam } \\
\cline { 2 - 10 } & \multicolumn{1}{c}{$\mathrm{N}$} & $\%$ & $\mathrm{~N}$ & $\%$ & $\mathrm{~N}$ & $\%$ & $\mathrm{~N}$ & $\%$ \\
\hline Ayda bir & 23 & 20,5 & 55 & 27,2 & 55 & 30,2 & 133 & 26,8 \\
Ayda birkaç kez & 12 & 10,7 & 36 & 17,8 & 50 & 27,5 & 98 & 19,8 \\
Tatile ç1kmadan önce & 13 & 11,6 & 14 & 6,9 & 14 & 7,7 & 41 & 8,3 \\
Uygun olduğunda & 64 & 57,1 & 97 & 48,0 & 63 & 34,6 & 224 & 45,2 \\
\hline Toplam & 112 & 100,0 & 202 & 100,0 & 182 & 100,0 & 496 & 100,0 \\
\hline \multicolumn{1}{c}{$\left(\chi^{2}=23,27 ; p<.001\right)}$. & & & & & & &
\end{tabular}

Tablo 7'de özel okula devam eden çocukların annelerinin \%34,6'sı (n=63); devlet okuluna giden çocukların \%48,0'inin $(n=97)$ ve okula gitmeyen çocukların ise \%57,1'inin $(n=64)$ kendilerine uygun olduğunda kitap aldıkları görülmektedir. Ayrıca okula gitmeyen çocukların annelerinin 10,7'sinin $(\mathrm{n}=12)$ ayda birkaç kez kendilerine kitap aldıkları görülmektedir. Çocukların devam ettikleri okul türüne göre annelerin kendilerine kitap alma sıklıkları arasında istatistiksel olarak anlamlı fark vardır.

Tablo 8.

Çocukların Devam Ettikleri Okul Türüne Göre Annelerin Çocuklarına Kitap Alma Sıklığının Dağılımı

\begin{tabular}{lllrrrrrr}
\hline & \multicolumn{2}{l}{$\begin{array}{l}\text { Okula } \\
\text { Gitmiyor }\end{array}$} & \multicolumn{2}{c}{ Devlet Okulu } & Özel Okul & \multicolumn{2}{c}{ Toplam } \\
\cline { 2 - 9 } & \multicolumn{1}{c}{$\mathrm{N}$} & $\%$ & $\mathrm{~N}$ & $\%$ & $\mathrm{~N}$ & $\%$ & $\mathrm{~N}$ & $\%$ \\
\hline Her ay bir kez & 4 & 3,5 & 21 & 10,3 & 29 & 15,7 & 54 & 10,8 \\
Her ay birkaç kez & 9 & 8,0 & 28 & 13,7 & 40 & 21,6 & 77 & 15,3 \\
Ara sira & 49 & 43,4 & 62 & 30,4 & 57 & 30,8 & 168 & 33,5 \\
Çocuğum istediğinde & 21 & 18,6 & 64 & 31,4 & 46 & 24,9 & 131 & 26,1 \\
$\begin{array}{l}\text { Ekonomik durumum } \\
\text { elverdiğinde }\end{array}$ & 30 & 26,5 & 29 & 14,2 & 13 & 7,0 & 72 & 14,3 \\
\hline Toplam & 113 & 100,0 & 204 & 100,0 & 185 & 100,0 & 502 & 100,0 \\
\hline
\end{tabular}

$\left(\chi^{2}=46,43 ; p<.001\right)$.

Tablo 8'de özel okula devam eden çocukların \%30,8'ine $(\mathrm{n}=168)$; okula gitmeyen çocukların annelerinin \%43,4'üne $(\mathrm{n}=49)$ ara sıra kitap alındığı; devlet okuluna giden çocukların annelerinin \%31,4'üne $(\mathrm{n}=46)$ ise çocuk istediğinde kitap alındığı; okula gitmeyen çocukların annelerinin ise \%3,5'inin $(n=4)$ çocuklarına her ay bir kez veya her ay birkaç kez kitap aldıkları görülmektedir. Çocukların devam ettikleri okul türüne göre annelerin çocuklarına kitap alma sıklıklarına ilişkin görüşleri arasında istatistiksel olarak anlamlı fark göstermektedir.

Tablo 9'da özel okula devam eden çocukların \%37,8'i $(\mathrm{n}=70)$; devlet okuluna giden çocukların \%47,6'sı $(\mathrm{n}=98)$ ve okula gitmeyen çocukların ise \%25,0'ine $(\mathrm{n}=28)$ kitap alınırken annelerinin fikirlerini aldığını belirtmektedir. Çocukların devam ettikleri okul türüne göre kendilerine kitap alınırken tercihi kimin yaptığı istatistiksel olarak anlamlı bir fark göstermektedir. 
Tablo 9.

Çocukların Devam Ettikleri Okul Türüne Göre Kendilerine Kitap Alınırken Tercihi Kimin Yaptığına İlişkin Sonuçlar

\begin{tabular}{|c|c|c|c|c|c|c|c|c|}
\hline & \multicolumn{2}{|c|}{ Okula Gitmiyor } & \multicolumn{2}{|c|}{ Devlet Okulu } & \multicolumn{2}{|c|}{$\begin{array}{l}\text { Özel } \\
\text { Okul }\end{array}$} & \multicolumn{2}{|c|}{ Toplam } \\
\hline & $\mathrm{N}$ & $\%$ & $\mathrm{~N}$ & $\%$ & $\mathrm{~N}$ & $\%$ & $\mathrm{~N}$ & $\%$ \\
\hline Anne & 18 & 16,1 & 48 & 23,0 & 29 & 15,7 & 95 & 18,9 \\
\hline Baba & 15 & 13,4 & 2 & 1,0 & 5 & 2,7 & 22 & 4,4 \\
\hline Anne-baba birlikte & 26 & 23,2 & 40 & 19,4 & 47 & 25,4 & 113 & 22,5 \\
\hline Çocuğun fikrini alma & 28 & 25,0 & 98 & 47,6 & 70 & 37,8 & 196 & 39,0 \\
\hline Öğretmenine sorma & 4 & 3,6 & 11 & 5,3 & 31 & 16,8 & 46 & 9,1 \\
\hline Kitapçıya danışma & 21 & 18,8 & 7 & 3,4 & 3 & 1,6 & 31 & 6,2 \\
\hline Toplam & 112 & 100,0 & 206 & 100,0 & 185 & 100,0 & 503 & 100,0 \\
\hline
\end{tabular}

\section{Tartıșma / Sonuç ve Öneriler}

Okula gitmeyen çocukların kitaptan hoşlanma oranının diğer gruplara göre düşük olması aynı şekilde hoşlanmama durumlarının ise daha yüksek olması dikkat çeken bir durumdur. $\mathrm{Bu}$ durumun çocukların kitabı sevmelerinde etkili olan kaliteli kitaplar ile sık karşılaşmamalarından kaynaklandığı düşünülmektedir. Zira okula gitmeyen çocukların annelerinin evhanımı olduğu dikkate alınırsa bu konuda bilinçli hareket edebilecekleri ortama sahip olmamaları da bu durumu etkileyebilir.

Ailelerin eğitim seviyeleri yükseldikçe çocuklarına kitap seçerken daha çok çocukların isteklerini göz önünde bulundurmalarından daha bilinçli ve özenli davrandıkları söylenebilir. Özellikle okula gitmeyen çocukların annelerinin "param olduğu için" yüksek oranda (\% 29,1) kitap almayı tercih etmesi bu konuda bilinçli hareket etmediklerini gösteren bir diğer bulgudur. Çocuklar için yazılmış edebi eserler çocukların öğrenme ve bilgilenmeleri için önemli kaynaklardır. Bir çocuk kitabı çocuğun ilgi ve ihtiyaçlarını karşılamasını yanında kendisine okunmasından zevk aldığı bir eser olmalıdır (Chiristie, Vukelich ve Roskos, 2013; Donoghue, 2009; Morrow, 2007; Santora, 2013; Sawyer, 2009; Robert ve Crawford, 2008). Çocuklar erken dönemde kitapla doğru bir şekilde tanıştırılır ve çocuğun ilgi ve ihtiyacına uygun ve zevk aldığ eserler olursa çocuklar kendi iradeleriyle ebeveynlerinden kitap almalarını isteyebilirler (Gündüz, 2007). Tablo 2'teki sonuçlar literatür ile benzerlik göstermektedir.

Çocukları okula gitmeyen annelerin yüksek oranda $(\% 33,6)$ boyama kitaplarını tercih etmeleri bu tür kitaplara erişimin kolay olmasından ve çocuklarına etkinlik olsun düşüncesiyle hareket etmelerinden kaynaklanabilir. Ancak kavram geliştirici kitapları daha yüksek oranda tercih etmeleri bunun ipucu olabilir. Ancak boyama kitaplarının çocuklarının yaratıcılığının gelişimini olumsuz yönde etkilediği düşünüldügünde bu konuda yine bilinçsiz hareket ettikleri söylenebilir. Devlet okulu ve özel okula devam eden çocukların annelerinden de boyama kitabı alanların olması bu kitaplara erişimin kolay olmasından kaynaklanıyor olabilir. Özellikle boyama kitaplarını çocuklar istediği için ve marketlerde en ucuz ve en çok yeralan kitaplar arasında olmaları nedeniyle anneler bilinçlide olsa boyama kitabı almayı tercih ediyor olabilir. Yapılan araştırmalarda ailelerin çocuklarına kitap seçimi sosyo ekonomik düzeyi ile ilgili olduğu ve gelir düzeyi düştükçe ailelerin kitapların eğitsel özelliklerini göz önünde buldurmadıkları tespit edilmiştir (Gündüz, 2007). Okul öncesi çocukları için, onların yaş ve ilgi düzeylerine uygun olduğu takdirde, tüm edebi türdeki kitaplar gereklidir. Bu yaş grubundaki çocuklar farklı temalar, konular, resimlemeler ve boyutlarda kitaplarla tanıştırılmalıdır (Chiristie ve diğerleri 2013; Gürkan, 1993; White, 2005). Özellikle okul öncesi dönem çocukları için klasik masallar uygun değildir. Masallardaki olağanüstü kahramanların çocukları olumsuz yönde etkileyebilmektedir. Bazı ebeveynlerin çocuklarına klasik masal alması ebeveynlerin bu konudaki bilinç düzeylerinin düşük olması ile ilişkili olabilir. $\mathrm{Bu}$ yaş döneminde gelişim 
düzeylerine uygun olduğu takdirde her tür kitapla tanıştırılması doğru olarak değerlendirilmektedir.

Özellikle okula gitmeyen annelerin daha düşük oranda $(\% 7,1)$ çocuklarına hediye olarak kitap almayı tercih etmeleri kitabın hediye olabileceği ve çocuğun ilgisini çekebileceğini düşünmesinden kaynaklanabilir. Şeker ve çikolatay $\% 13,3$ oranında tercih etmelerinde bilgili ve bilinçli hareket ettiklerini gösteren bir diğer bulgu olabilir.Oyun, çocuğun gelişiminin temel yapı taşıdır. Çocuklar severek ve isteyerek her koşulda oyun oynamaktadırlar. Bu dönemde çocuğun en önemli işi oyun, en önemli aracıda oyuncaktır (Anderson-McNamee ve Bailey, 2010; Guyton, 2011; Poyraz, 2003; Tuğrul, 2015). Çocuklar kendilerine oyuncak alındığında çok mutlu olurlar. Bu nedenle ebeveynler yüksek oranda çocuklarına hediye alırken oyuncağa öncelik verdikleri düşünülmektedir. Oyuncağı en çok annelerin aldığı, yetişkinlerin oyuncak alırken çocukların isteklerini göz önünde bulundurduğu çocuklarına daha sık oyuncak aldıkları tespit edilmiştir (Bolışık, Yılmaz, Yavuz ve Büyük, 2014; Uğurlu, Özet ve Ayçiçek, 2012). Tablo 4'teki sonuçlar literatür ile benzerlik göstermektedir.

Okula devam etmeyen annelerin çocuklarının arkadaşlarına hediye olarak giysiyi yüksek oranda oyuncak ve kitabı ise diğer annelere göre daha düşük oranda tercih etmeleri dikkate değer bir bulgudur. Bu sonuç diğer 4 . Tabloda olduğu gibi yine annelerin bu konuda yetersiz donanıma sahip olmasından kaynaklanabilir.

Çocuk Kütüphaneleri, çocukları yaşam boyu öğrenme ve okuryazarlık becerileri kazanmalarına destek olmak ve onların topluma katılım ve katkı sağlamalarını amaçlayan kurumlardır (International Federation of Library Associations and Institutions, [IFLA], 2011). $\mathrm{Bu}$ dönem çocuklar için, gelişim düzeylerine uygun zengin kaynakların ve uzman kişilerin bulunduğu ortamlardan faydalanmalarını sağlamak ve bu mekanlarda hoş vakit geçirmelerine olanak sağlamak çok önemlidir. Okul öncesi dönem çocuklarına kurumlarda verilen hizmetler paralıdır. Ancak, her çocuğun kolaylıkla ve ücretsiz olarak hizmet alabileceği ve ona zengin kaynaklara sahip ve uzman kişilerin görev yaptığı kütüphanelerdir. Halk kütüphanelerinin çocuk bölümleri ve çocuk kütüphaneleri çocukların ücretsiz olarak nitelikli edebi eserlerle karşılaşmaları onların ileride iyi okuyucu olabilmeleri açısından önemlidir (Yılmaz, 2008; Yükselen, 2015). Çocuklarını özel okul ve devlet okuluna gönderen ailelerin çocuklarını okula göndermeyen ailelere göre daha yüksek düzeyde göndermeleri okulların aileleri teşvik etmeleri ve ailelerin bu konuda bilinçlenmeleri çocukları okula gitmeyen annelerin ise bu konuda herhangi bir bilgiye sahip olamamalarından kaynaklanabilir.

Çocukları özel ve devlet okuluna giden annelere oaranla çocukları okula gitmeyen annelerin kendilerine daha düşük oranda kitap almaları kendilerine kitap alma alışkanlığının olmamasından kaynaklanabilir.

Okula gitmeyen çocukların annelerinin diğer annelere oranla kendilerine daha geç aralıklarla kitap almayı tercih ettikleri görülmektedir. Bu sonuç annelerin kitabın okula gidilince alınabilecek bir materyal olduğunu düşünmelerinden kaynaklanabilir.

Özellikle okula gitmeyen çocukların annelerin kitapçıya danışma oranının \% 88 diğer annelere göre daha yüksek olması dikkate değer bir bulgudur. Çocuklar için nitelikli kitap seçme çocukların gelişimi için çok önemlidir. Nitelikli kitap seçmek için çocukların ilgilerini ve gelişim düzeylerini gözönünde bulundurulmalıdır (Chiristie ve diğerleri 2013; Donoghue, 2009). Kitapçılarda, okul öncesi çocuklarına yönelik olarak yayınlaşmış pek çok kitap bulunmaktadır. Ne yazık ki hiçbir edebi ve eğitsel değer taşımayan eserlerde kitapcılarda satılmaktadır. Görünüş olarak çekici olan ve bazılarını ise çok ucuza teminedinilebilen bu eserlerin bir çoğu resinmleme, konu, dil vb. açısından çocuklar için uygun olmayan eserlerdir. Çocukların gelişim düzeyine, ilgi ve ihtiyacına uygun olmayan ve kendisine okunduğuna zevk almadığı eserler çocukta kitaba ve okumaya karşı olumsuz bir tutum geliştirmesine neden olabilmektedir. Bu nedenle, anne ve babaların ve öğretmenlerin çocuklarına kitap seçerken kitapların çocuğun gelişim, ilgi ve ihiyacına uygun nitelikli edebi eserler olmasına dikkat etmelerini zorunlu hale getirmektedir (Gönen, Uzmen ve Çakmak, 1994; Oğuzkan, 2000). Bu noktada diğer tablolardaki sonuçlarla birlikte sonuç ele alındığında annelerin satın almada doğru 
yönlendirilmediği, düşünülmektedir. Kitap satıcılarının gerek mali çıkar gerekse bu konuda bilinçli olmamaları nedeniyle bu sonuç ortaya çıkmış olabilir.

Sonuç olarak, ailelerin eğitim seviyeleri yükseldikçe çocuklarına kitap seçerken daha çok çocukların isteklerini göz önünde bulundurmalarından daha bilinçli ve özenli davrandıkları söylenebilir. Ailelerin çocuklarına kitap seçimi sosyo ekonomik düzeyi ile ilgili olduğu ve gelir düzeyi düştükçe ailelerin kitapların eğitsel özelliklerini göz önünde buldurmadıkları tespit edilmiştir. Öğretmenlerin, çocuk kitabı seçimi ve kütüphanden verimli bir şekilde yararlanabilmeleri için ebeveynleri bilgilendirmeleri gerekmektedir. Çocukları kuruma devam eden ebeveynler aile katılım çalışmaları kapsamında; çocuklarını okula göndermeyen ebeveynlere ise kamu spotları ve halk eğitim merkezleri aracılığıyla bilgilendirilebilir. Bunun aynı zamanda toplumsal bir sorumluk olduğu da düşünülmelidir.

\section{Kaynaklar}

Anderson-McNamee, J. K. ve Bailey, S. J. (2010). The importance of play in early childhood development. Erişim adresi: http://store.msuextension.org/publications/HomeHealthand Family/MT201003HR.pdf.

Beyazova, U. (2006) Kitap çocuk ilişkisi. S. Sever (Yay. haz.). II. Ulusal Çocuk ve Gençlik Edebiyatı Sempozyumu, 04-06 Ekim 2006, Ankara, Türkiye, Bildiriler, içinde (ss. 533537). Ankara: Ankara Üniversitesi.

Bolışık, B., Yılmaz, H. B., Yavuz, B. ve Büyük, E. T. (2014). Yetişkinlerin çocuklar için oyuncak seçimine yönelik davranışlarının incelenmesi. Gümüşhane Üniversitesi Sağllk Bilimleri Dergisi, 3(4), 976-990.

Brock, A. ve Rankin, C. (2008). Communication, language and literacy from birth to five (First edition). London: Sage Publications.

Büyüköztürk, Ş. (2012). Veri analizi el kitabı. (8. Baskı). Ankara: Pegem A Yayıncılık.

Chiristie, J. F., Enz, B. J., Vukelich, C. ve Roskos, K., A. (2013). Teaching language and literacy. Boston: Pearson Publication.

Epspinosa, L. M. ve Burns, M. S. (2003). Early literacy for young children and English language learners. C. Howes (Yay. haz.), Teaching 4-to 8-years-olds, içinde (ss.47-59). Los Angeles: Paul. H. Brookes Publising.

Ersoy, Ö., Avc1, N. ve Turla, A. (2006). Çocuklar için erken uyarıcı çevre. İstanbul: Morpa Kültür Yayınlar.

Ersoy, Ö. ve Bayraktar, V. (2015). Annelerin öğrenim durumlarına göre çocuklarını kitapla buluşturma konusundaki durumlarının incelenmesi (Çalışma kapsamı 57 İl). İlköğretim Online, 14(4), 1406-1415. doi.org/10.17051/io.2015.42378

Detemple, J. M. (2001). Parents and reading books together. K. D. Dickinson ve P. O. Tabors (Yay. haz.), Begining literacy with language. London, Sydney: Paul H. Brooke Publishing.

Donoghue, M. R. (2009). Language arts. London: Sage Publications.

Gönen, M., Uzmen, S. ve Çakmak, H. (1994). Türkiye'deki resimli çocuk kitaplarının fizik, içerik ve resimlendirme yönünden incelenmesi. 10. Ya-Pa Okul Öncesi Ë̆itim Semineri, 8-10 Ekim 1994, İstanbul: Ya-Pa Yayın Pazarlama.

Griffith, P. L., Beach, S. A., Ruan, J. ve Dunn, L. (2008). Literacy for young children. London: Corwn Press.

Guyton, G. (2011). Using toys to support infant-toddler learning and development. Erişim adresi: https://www.naeyc.org/files/yc/file/201109/Using\%20Toys_Guyton_Online_ 0911.pdf

Gündüz, A. (2007). Anne-baba ve ögretmenlerin okul öncesi çocuk kitaplarını değerlendirmesi (Yayımlanmamış yüksek lisans tezi). Afyonkarahisar: Kocatepe Üniversitesi Sosyal Bilimler Enstitüsü.

Gürkan, T. (1993) Okul öncesi eğitimde kitap. 9. Ya-Pa Okul Öncesi Ĕgitimi ve Yaygınlaştırılması Semineri. Ankara: Ya-Pa Yayın Pazarlama. 
Hardman, M. ve Jones, L. (1999). Sharing books with babies: evaluation of an early literacy intervation. Educational Review, 51(3), 221-229, DOI: /10.1080/00131919997461

Huck, C. S., Kiefer, B. Z., Hepler, S. ve Hickman, J. (2004). Children's literature in the elementary school (Eight Edition). The University of Michigan: McGraw-Hill Pulication.

International Federation of Library Associations and Institutions (IFLA) (2011). Çocuk Kütüphanesi Hizmetleri İçin Ilkeler. Erişim adresi: https://www.ifla.org/files/assets /libraries-forchildren-andya/publications/guidelines-for-childrens-libraries-services tr.pdf

Machado, J. M. (2003). Early childhood experience in language arts emerging literacy. Canada: Delmar Learning.

Morrow, L. M. (2007). Developing literacy in preschool. New York. London: The Guilforf Press.

Oğuzkan, F. (2000). İyi bir çocuk kitabın, çocuğun ruhsal ve düşünsel gelişimine katkısı var mıdır? M. R. Şirin (Yay. haz.). 99 Soruda Çocuk Edebiyatı içinde (s.210-212). İstanbul: Çocuk Vakfı Yayınları.

Oktay, A. (2002). Yaşamın sihirli yılları: Okul öncesi dönem (4. Baskı.) İstanbul: Epsilon Yayınevi.

Özel, A. (2006). Okul öncesi dönemde görsel açıdan çocuk kitapları. O. Ramazan, K. Efe ve G. Gülçin (Yay. haz.). I.Uluslararası Okul Öncesi Eğitim Kongresi, 3-6 Ekim 2006, Bildiriler, içinde (ss. 241-250). İstanbul: Ya-Pa Yayın Pazarlama

Poyraz, H. (2003). Okul öncesi dönemde oyun ve oyuncak. Ankara: Anı Yayınc1lı.

Roberts, S. K. ve Crawford, P. A. (2008). Literatüre to help children cope with family stressors. Erişim adresi: https://www.naeyc.org/files/yc/file/200809/Crawford.pdf

Santora, L. A. (2013). Assessing children's book collections using an anti-bias lens. Erişim adresi: www.adl.org

Sawyer, W. E. (2009). Growing up with literature (Fifty Edition). United States of America: Delmar.

Soderman, A. K., Gregory, K. M. ve McCarty, L. T. (2005). Scaffolding emergent literacy. United States of America: Pearson Education.

Tuğrul, B. (2015). Oyunun gücü. A. B. Aksoy (Yay. haz.), Okul Öncesi Dönemde Oyun, içinde (ss. 209-230). Ankara: Hedef CS Basin Yayın.

Tuncer, N. (2000). Çocuk ve kitap. M. R. Şirin (Yay. haz.). 99 Soruda Çocuk Edebiyatı, içinde (ss. 198-202). İstanbul: Çocuk Vakfı Yayınları.

Tür, G. (2001). Okul öncesi eğitimde kitap seçimi. Gazi Üniversitesi Anaokulu/Anasinıfi Öğretmeni El Kitabı, içinde (ss. 416-423). İstanbul: Ya-Pa Yayınları

Uğurlu, E. S; Özet, F. ve Ayçiçek, D. (2012). Examinations of knowledge and applications about toy selections of mothers who have child 1-3 age group. International Journal of Human Sciences. 9(2), 879-891. Erişim adersi: file:///C:/Users/-VEDAT/Downloads/ 2243-6871-1PB\%20(1).pdf

Yılmaz, A. (2008). Okulöncesi çocuklara yönelik kütüphane hizmetlerinin önemi ve başarılı bir kütüphane örneği. Türk Kütüphaneciliği, 22(2), 169-186.

Yurdagül, H. (2005). Ölçek geliştirme çalışmalarında kapsam geçerliği için kapsam geçerlik indekslerinin kullanılması. XIV Ulusal Eğitim Bilimleri Kongresi, 28-30 Eylül 2005, Denizli, bildiriler içinde (ss. 1-6), Denizli.

Yükselen, A. İ (2015). Okul öncesinde çocuk ve medya. A. Turla. (Yay. haz.). Okul Öncesi Dönemde Çocuk Edebiyatı içinde Ankara: Hedef CS Basın Yayın.

White, H. (2005). Developing literacy skills in the early years. London: Paul Chapman Publising.

Wortham, S. C. (2005). Early childhood curriculum. New Jersey, Columbus, Ohi: Pearson Merill Prentice Hall. 


\section{Extended Abstract}

\section{Introduction}

Early childhood is known as forming the basis of development and shaping children's personalities. Core knowledge, skills and habits that are learned in this period are seen as the predictors of children's later academic achievement. For this reason, a child's education, experiences and opportunities provided to the child becomes important for the individual. Moreover, rich and stimulating environments are regarded necessary for supporting children's development and the books are crucial parts of these environments. Therefore, one of the habits that should be formed in early childhood period is reading habit and love for reading. To form reading habit and love for reading in preschool period, families and preschool teachers can make a significant contribution to children's environments by providing children books.

Experiences related with books in early childhood determines children's attitudes and emotions toward learning to read for their later academic achievement. Since children take other children and adults as a role model at these ages to form habits, experiences are substantial in these years (Gürkan, 1993).

Parents are children's first teachers. Therefore, they have a prominent role on children to have positive feelings toward reading. Additionally, children's interest and perception to literacy are directly proportionate to parent's attitudes. For this reason, to have positive attitudes toward books and literacy, parents are to read books for their children (Epspinosa \& Burns 2003; Griffith et al. 2008; Machado, 2003; Wortham, 2005).

Books are important stimulators to support children's development in early childhood period. Reading storybooks improves children's language skills, helps them to enjoy language learning, increase their vocabulary and thinking skills. Additionally, it is found that reading books at early ages is directly proportionate to children's later academic achievement and reading success. In other words, literacy and language experiences at nursery and preschool level affects children's later school success (Brock \& Rankin 2008; DeTemple, 2001; Epspinosa \& Burns, 2003; Ersoy \& Bayraktar 2015; Griffith et al. 2008; Huck et al. 2004; Wortham, 2005).

Books should be introduced to babies when they start to be interested in pictures and recognize objects as from when they are six months old. As a matter of fact, it is proven with studies that babies examine storybooks and react to readings (Beyazova, 2006; Huck et al. 2004; Machado, 2003; Özel, 2006; Soderman et al. 2005).

Establishing a positive relation between child and book is associated with choosing appropriate books according to their age, developmental level, interest and needs. Therefore, parents' priority should be knowing their children's interests based on different stages of growth and literacy resources. There are number of differences in the parts of storybooks according to children's ages. To illustrate, there are differences both in terms of outside and inside parts of books prepared for children aged 1-2 years and for children aged 3-6 years. At the same time, this situation helps to increase children's love for books, and so children who love books become more likely to be a good reader in the future. Hence, it is necessary to introduce children with books according to their age, interests and needs at early ages. To sum, choosing and using the right book is an important factor that helps to reach the goal of instilling children love for books (Epspinosa \& Burns, 2003; Ersoy et al.2006; Hardman \& Jones, 1999; Oğuzkan, 2000; Tür, 2001).

The purpose of this study is to determine mothers' opinions on children's books according to school types that their children attended in Turkey. With this study, problems in this field will be identified and solution strategies will be developed.

\section{Method}

Survey method was used in the study. A total of 500 mothers living in Ankara city center and selected by appropriate sampling method have participated in the research. The data has been analyzed with Chi Square (X $\left.{ }^{2}\right)$ in the SPSS 20.00 package program. "Questionnaire for selection 
of children's books for children in preschool period" has been applied to the mothers. The mothers in the questionnaire have been asked about the reasons for the children to receive books, how to buy books for their children, what kind of books they chose for their children, what they received as prize and gifts for their children, what they received as prize and gifts for their friends, the frequency of taking books with their children, and the questions about who made the choice while taking the book to the children.

\section{Results and Discussion}

In the result of the research a statistically significant difference has been found in the subjects: the case of the children's like bought themselves book $(\chi 2=9,83 ; \mathrm{p}<.001)$, book purchase reasons $(\chi 2=42,29 ; p<.001)$, the distribution of prize or gifts they receiving for their children $(\chi 2=27,04 ; \mathrm{p}<.001)$, mothers taking their children to the library $(\chi 2=72,43 ; \mathrm{p}<.001)$, the distribution of prize or gifts children buying their friends $(\chi 2=33,10 ; \mathrm{p}<.001)$, the frequency of taking books for themselves $(\chi 2=23,27 ; \mathrm{p}<.001)$, the frequency of mothers taking books for their children $(\chi 2=46.43, \mathrm{p}<.001)$ and who make the choice while they are buying the book $(\chi 2=98,57 ; \mathrm{p}<.001)$; but there was no statistically significant difference in what kind of books they preferred to their children.

It can be supposed that as the education levels of the parents increase, they tend to be more conscious and attentive while choosing books for their children by mostly considering children's wishes. Consequently, it is found that parents' book choices are related with their socioeconomic level and as the level of income decreased, parents do not consider educational value of books. 